\title{
The Transformation of Northeast Asian States in the Era of Globalization: \\ Regulatory State or Flexible Developmental State?
}

\author{
Seung-Gook Ahn \\ (Hankuk University of Foreign Studies)
}

\section{$\langle$ Contents $\rangle$}

I. Introduction

II. Developmental States and Industrial Policies in Northeast Asia

III. The Role of Developmental States in Northeast Asian Growth
IV. Globalization and Developmental States

V. Flexibility of Developmental States in Northeast Asia

VI. Conclusion

- Key Words: bureaucratic developmental state, flexible developmental state, regulatory state, Industrial policy, the role of the state, globalization, Northeast Asia

\section{【ABSTRACT 】}

This paper provides an analysis of the effects of globalization on Northeast Asian developmental states. What is the future fate of the developmental state in the era of globalization? To answer this question, it is helpful to review the conditions under which it is more likely to succeed or fail. The developmental state consisted of three elements. First, Northeast Asian developmental states placed top priority on economic development, which was often operationalized in terms of growth, productivity, and competitiveness. Second in order to achieve these broadly defined goals, the state intervened in the market to guide, discipline and coordinate the private sector through strategic allocation of resources and the use of diverse policy instruments. Third, the success of strategic intervention by the state was ensured by rational and competent bureaucrats. However, the developmental state appeared too rigid to cope with rapidly changing circumstances. The developmental state also appeared too weak to mange the

* This work was supported by Korea Research Foundation Grant (KRF-2001-041-C00111). 
changing circumstances. The developmental state also appeared too weak to mange the globalizing economies as evidenced in the economic crisis of 1997 and 1998. Northeast Asian states have been transformed from the bureaucratic model that characterized the economic success to the flexible one. The flexible developmental state is defined by its ability to nurture production networks, to attract foreign direct investment, and to link local and global business networks together in ways that promote development. The flexible developmental state model, therefore, can be presented as a solution to the dilemmas of the bureaucratic developmental state in the era of globalization.

\section{Introduction}

In the 1990s, Northeast Asian counties including South Korea and Taiwan were forced to meet the challenges of transformation, and especially critical was how they would deal with globalization. Regardless of strategies that each country employed to address such an important task, the fundamental aim for all states was to readjust and modify the role of the state. The neo-mercantile developmental state model, the locomotive behind the phenomenal growth of the past four decades, had lost most of its efficiency, with the globalization of products, services and capital evolving around the market, not around the state. State policy had become less effective and more problematic even in the domestic domain.

Against this backdrop, Northeast Asian countries were in dire need of a new state model that focused on curtailing excessive intervention, instead promoting economic dynamism and efficiency. Increasing accessibility of businesses to the international capital market significantly reduced their financial dependence on the state. With easier access to international capital, businesses and market refused state intervention. The increasing movement of international capital posed a serious challenge to the role of the developmental state, which necessitated a change in the state model, which had controlled the market through its ability to allocate funds. As businesses increasingly depended on the international financial market, through capital replacement, however, businesses no longer had to obey the state. At the same time, authoritarian governments made way for democratically elected officials, calling for changes in the old developmental state model.

Yet, rising international capital inflow also required the state's supervisory role. In the volatile international capital market, the state has to properly monitor capital movement. In the globalizing world, economic growth depends on deregulation, free trade and attraction of foreign capital. From the early 1990s, the driver for growth shifted from state financing to international capital, which streamlined the liberalization and deregulation process in the domestic market. In an effort to address issues of foreign debt and to attract investment, developing countries accepted the free market's role of allocating economic resources and voluntarily joined the WTO(World Trade Organization).

Globalization not only stresses the importance of a self-regulatory market, but also guarantees 
the right to participate in the global market. The central question of this paper is whether the role of Northeast Asian states has been successfully replaced by the self-regulatory market. It appears that Northeast Asian states have a more flexible role than in the old state model, which retains some characteristics of the developmental state. Therefore, this paper will also discuss how the state's role must evolve in order to achieve development in the era of globalization.

To accomplish this research goal, this paper looks at the changes taking place in terms of the role of Northeast Asian states. First, there is a discussion on the developmental state, which leads to discussion of globalization's impact on developmental states. Second, this paper proposes the flexible developmental state modified from the old state model. Third, options are presented for Northeast Asian countries: the neo-liberalistic regulatory state or the flexible developmental state.

\section{Developmental States and Industrial Policies in Northeast Asia}

The term developmental state refers to the state that plays a critical role in economic development through planning and organization based on strategic targets. In this context, developmental states can be defined as follows1): First, Northeast Asian developmental states found priority in economic development, in which the key goals were growth, productivity and competition. Second, in pursuit of economic success, the state aggressively intervened in the market, guiding and controlling it and the private sector by the strategic allocation of resources. Third, behind the success of the state's strategic intervention lay an efficient and rational bureaucracy. Bureaucratic autonomy free from social pressure, in particular, did not result in rent-seeking or looting.

Studies on the developmental state burgeoned after state intervention was widely acknowledged in the 1980s as a main force behind the economic success and rapid industrialization of Northeast Asian countries. ${ }^{2)}$ Chalmers Johnson pioneered studies on the developmental state, examining the keys to phenomenal growth of Northeast Asian economies based on his capitalist developmental state concept.3) The developmental state's foremost goals were growth, productivity and competitiveness, culminating in economic development that employed strategic industrial policy to realize the goal. The developmental state offered financing, planning, production and allocation. In particular, the developmental state led while the market followed, a concept consistent with the one

1) The foundation of Northeast Asian developmental states includes: the presence of centralized state and bureaucracy; overdeveloped state under the Cold War structure; vulnerability of capitalists and workers; and weakening of landlords caused by land reforms. The developmental state is based on Weberian bureaucratic organization, which is characterized by hierarchical organization, specialized job responsibilities, merit-based hiring, performance-based promotion, rule of law and occupational officials.

2) The theory of the developmental state is a second-generation theory that explains economic development in Northeast Asia. The first-generation theory, presented by neo-classical economists and the World Bank, emphasized that dynamic economic development of Northeast Asia was possible because of laissez-faire and open economy and that state intervention itself complied with market principles. For the first generation theory, refer to Bela Balassa, The Newly Industrializing Countries in the World Economy (New York: Pergamon, 1981).

3) Chalmers Johnson, MITI and the Japanese Miracle: The Growth of Industrial Policy, 1925-1975 (Stanford: Stanford University Press, 1982). 
followed by post-war Japan. Johnson's study criticized the neo-classical political economy under which state intervention invariably resulted in inefficiency and led to rent-seeking and corruption, and presented a new state concept.

In another study, Alice Amsden and Robert Wade analyzed the characteristics of industrial policy and its influences on economic performance.4) Amsden pointed out that performance-based subsidies played a significant role in late industrialization. State intervention in Northeast Asia was focused on price controls in an attempt to funnel into economic activities on investment. Industrial policy also meant state control over businesses. Since the state offered businesses subsidies based on performance, price distortions could be minimized, and resources efficiently allocated and utilized.5) This being the case, financing held fundamental significance in the success of industrial policies in Northeast Asia.

Amsden's analysis of South Korea is consistent with Johnson's view on MITI(the Ministry of International Trade and Industry) and its industrial policy in Japan. Amsden concluded that South Korea was the epitome of a disciplined market economy based on plan rationality. Unlike a free market economy, in a disciplined market economy, market rationality was restricted by the priority of industrial policy. The state curbed internal and external market pressures, and aligned business interests with national economic interests.

In addition, the state financially supported and supervised businesses to strengthen their international competitiveness. However, industries that were not so-called strategic industries were isolated from financial support and forced to compete in the market. Such strategic selection lay at the core of industrial policy. The market, therefore, was led by a long-term investment perspective. The state created a safe and predictable investment environment for businesses to mitigate long-term risk. And the high profit potential in the global market determined strategic industries.

\section{The Role of Developmental States in Northeast Asian Growth}

According to Johnson, economic growth of Northeast Asian countries like South Korea and Taiwan is fundamentally attributable both to the external factor of a new international division of labor and to internal factors of market creation induced by state intervention, the role of local capital and efficient production controls. That is, the state enforced import restrictions and established tariff barriers to protect local industries while utilizing state-controlled financial institutions as a vehicle to lead industrialization.6)

As Stephan Haggard stated, the state took on the role of mitigating risk when inducing foreign

4) Alice Amsden, Asia's Next Giant: South Korea and Late Industrialization (New York: Oxford University Press, 1989); Robert Wade, Governing the Market: Economic Theory and the Role of Government in East Asian Industrialization (Princeton: Princeton University Press, 1990).

5) Industrial policy of the developmental state in Northeast Asia channeled investment into sectors with growth potential. This aspect of Northeast Asia's industrial policy made it different from Western Europe's industrial policy, which sank investment into financially risky declining industries and distressed companies.

6) Chalmers Johnson, "Political Institutions and Economic Performance: The Government-Business Relationship in Japan, South Korea, and Taiwan," in Frederic C. Deyo, (ed.), The Political Economy of the New Asian Industrialism (Ithaca: Cornell University Press, 1987). 
capital, expanding infrastructure, providing technology support and offering market information.7) Northeast Asian countries, lacking technology competitiveness, pursued economic growth through state-offered incentives. Incentives went beyond a simple tariff measure or import restriction for local industry protection to include financial support, tax benefits and intensive investment to nurture promising industries. ${ }^{8)}$ In the process of industrialization, Northeast Asian states took on a relatively broad role of leading and regulating the market. Amsden emphasized that the state provided local businesses credit on favorable terms and tax benefits in order to drive exports. ${ }^{9}$ )

Gordon White and Robert Wade attempted to identify constraints that faced states, and also followed the changes that had occurred in terms of the nature of state intervention. Their study asked how the state influenced the economy in the context of globalization and they attempted to explain the confidence risk of economic development and the justification risk of development planning. ${ }^{10)}$ Wade, in particular, pointed out that analysis of institutional economics that concentrated on an effective combination of capitalist institutions failed to show how political factors affected economic performance. He presented a state-governed market as an alternative to previous studies, sharing that economic performance in Northeast Asian countries was driven by investment in strategic industries, state support, regulation and guidance for strategic industries and non-strategic industries' competition in the global marketplace.11) His analysis focused on the state's role of decision-making or goal-setting regardless of social opposition.

The developmental state was able to obtain a fine economic performance because it rose above the short-term pursuits of private businesses. The state, from a long-term perspective, enhanced the international competitiveness of private businesses through strategic investment, and promoted industrial structure and technology. The developmental state not only cultivated domestic businesses, but also grew industry by taking on a supervisory role. To accomplish this objective, the state implemented a selective, strategic protectionist policy. ${ }^{12)}$

Therefore, at the heart of the economic development of Northeast Asian countries existed the state's legal and institutional supports. The state had autonomy based on the classical Weberian concept of bureaucracy. Fundamental to such a state were capability-based recruits and promotion and procedural/rational norms. Autonomy guaranteed by bureaucrats has set economic development as the primary objective, and has allowed the state to collect information and mobilize resources. Given the distinction, the Northeast Asian state can be deemed as the bureaucratic developmental state.

Peter Evans also stressed that the developmental state was characterized by its role, based on a bureaucracy free of private interests. He claimed that the state had enough autonomy to set its

7) Stephan Haggard, Pathways from the Periphery: The Politics of Growth in the Newly Industrializing Countries (Ithaca, NY: Cornell University Press, 1990).

8) Seung-Gook Ahn, "The Political Economy of Capital Accumulation: the structural changes of the world economy and the East Asian NICs," The Korean Journal of International Relations, 36-3(1997), p.119.

9) Amsden(1989), p.14.

10) Gordon White and Robert Wade, "Developmental States and Markets in East Asia: An Introduction," in Gordon White, (ed.), Developmental States in East Asia (Sussex: Macmillan Press, 1988).

11) Wade(1990), pp.24-29.

12) Ziya Önis, "The Logic of the Developmental State," Comparative Politics, 24-1(October, 1991), pp.111-13. 
own objectives, and it established an industrial network to implement those objectives. The concept of embedded autonomy originated from the question of how developmental states put their objectives into practice. In that regard, Evans said that the immanence of the state made a successful economic transformation possible.

According to Evans, the developmental state had a link with the social sector, while preserving its autonomy from plural interests. Evans pointed out that the state facilitated the industrialization of developing countries. His idea focused on functional links between the state and the private sector. That is, links between the state and businesses were prerequisite to economic development and industrialization.

In particular, Evans emphasized the developmental state's connection to the society and introduced the concept of embeddedness, focusing on actors and institutions. He defined the developmental state's characteristic as an embedded autonomy, which is the combination of linkage and autonomy, and analyzed the influence of state intervention on economic performance. Depending on state intervention, there could be three types of the state: the developmental state, the predatory state and the intermediate state. ${ }^{13}$ )

According to the statist perspective, the state ignores the importance of social consensus given that it is the sole actor in policy decision and is superior to social groups. ${ }^{14)}$ As Joel Migdal stated, however, even the authoritarian state needed support from, and linkage with social groups in order to implement industrial policy.15) To that end, the state selected certain industries with political linkage to social groups and thus, the pattern of industrialization was created.

In other words, the state relied on cooperative relations with society for economic success. Collaboration between the state and businesses led to two very important results as follows: First, separation of economic decision from political influence allowed long-term planning and adjustment, which were critical to economic development. Second, the state was able to set and prioritize objectives of intensive development in collaboration with business groups. ${ }^{16)}$ However, the bureaucratic developmental state maintained close links with capital but excluded labor. ${ }^{17)}$ The dilemma of the bureaucratic developmental state is that as domestic businesses grow and gain

13) The predatory state drew economic surplus that could be invested, while providing no support for economic development or industrial transformation. The developmental state, meanwhile, motivated businesses to engage in production and investment and provided long-term plans. Evans took Zaire, under the Mobutu regime, as the epitome of the predatory state. He cited Japan, South Korea and Taiwan as developmental states and Brazil and India as intermediate states. Peter Evans, Embedded Autonomy: States and Industrial Transformation (Princeton, New Jersey: Princeton University Press, 1995), pp.45-70.

14) Stephen D. Krasner, Defending the National Interest: Raw Materials Investments and U.S. Foreign Policy (Princeton: Princeton University Press, 1978), pp.10-13, pp.56-57. Despite the criticism that the developmental state is not always a sole actor, the internal structure of a state does not necessarily have to be singular. The policy of a state can be regarded as a result of negotiation or agreement among internal organizations.

15) Joel Migdal, Strong Societies and Weak States: State-Society Relations and State Capabilities in the Third World (Princeton: Princeton University Press, 1988).

16) Linda. Weiss and John M. Hobson, States and Economic Development: A Comparative Historical Analysis (Cambridge: Polity, 1995), p.178.

17) Frederic C. Deyo, "State and Labor: Modes of Political Exclusion in East Asian Development," in Frederic C. Deyo, (ed.), The Political Economy of the New Asian Industrialism (Ithaca: Cornell University Press, 1987). 
international competitiveness, the alliance between the state and business weakens. In the 1990s, Northeast Asian businesses' internationalization and integration into the international financial market threatened the state-capital alliance, which had served as a cornerstone of growth in the region.

\section{Globalization and Developmental States}

The evolution of globalization has brought about theoretical debate among statists and globalists as to the role of the state. Views vary, not only on the concept and characteristic of globalization, but also on the weakening of national sovereignty. Production and consumption on the global level, and the globalization of finance have drastically changed the state's role in the economic sector. That is, a state's power to control was restricted by external factors. The development of transport and communications and the fledgling transnational corporations are transcending territorial boundaries. According to this view, the role and capacity of the state have weakened, while transnational corporations have increased their influences. ${ }^{18)}$

Therefore, a state's economic policy is considerably affected by the WTO and the changing international market. Globalists also emphasize that the nation-state is affected by globalization, and the action taken by the nation-state is spreaded out on the global scale. In other words, the retreat of state power and the contraction of its role are related to globalization. Production, allocation, and globalization of finance have changed the role of the nation-state in international political economy at a rapid pace. ${ }^{19)}$ Improvement of transport and communications, and the expansion of transnational corporations have enabled economic activities to reach beyond the territorial-borders that divide nation-states.

On the contrary, from the statist perspective, the state still plays an important role in maintaining sovereignty and policy-making irrespective of the globalizing economic sector. Statists insist that the global economy does not exist in actuality and that globalization itself is a myth. That is, although internationalization that recognizes the central role of the state may have evolved to a considerable degree, the existence of globalization in terms of scale and intensity is overstated. Thus, statists claim that the role of the nation-state in policy-making is underestimated. Statists emphasize the role of the state that corresponds to globalization. ${ }^{20)}$ They not only raise doubts about the concept of the global economy but conclude that the integration of the global economy is exaggerated. That is to say, internationalization has progressed in the economic sector but the globalization of the economy is an illusion. While statists acknowledge the autonomous role of the state in economic policy, they also recognize that the state's influence has weakened over time.21)

While there is a gap in perspective between statists and globalists, they share the idea that globalization has expanded on the level of international political economy, along with the changing

18) Susan Strange, The Retreat of the State (Cambridge: Cambridge University Press, 1996).

19) Kenichi Ohmae, The End of the Nation State: The Rise of Regional Economies (New York: The Free Press, 1995).

20) Robert Boyer and Daniel Drache, (eds.), States against Market: the Limit of Globalization (London: Routledge, 1996); Paul Hirst and Graham Thomson, Globalization in Question (Cambridge: Polity, 1996).

21) Hirst and Thompson(1996), pp.143-49. 
role of the nation-state. In particular, it is true that the extent and possibility of the nation-state's involvement in its macroeconomy within the framework of newly constructed global economy is being sharply reduced.

Against this backdrop, Northeast Asian states continue to play a supporting role in the development of national economy. From this point of view, privatization and deregulation are understood as part of the reconstruction of the state's capacity. Therefore, the core controversy over the state's role in the globalization process is not a matter of the market replacing the state's role, but of the state's adaptation in order to attract foreign capital and support local capital in the process of globalization.

Until quite recently, the developmental state has managed to practice cronyism, and to encourage cartels and monopolies. But these practices are no longer possible in the era of globalization. Bureaucratic developmental states formed the confederation of businesses, banks and state as a strategy that helped the economy to develop in the long term, but states after all faced an economic crisis due to the lack of flexibility.22) The centralized economic system lost competitiveness in the production market, where competitiveness was gained through the decentralization of the inter-corporate network. Also, because of its rigidity, the bureaucratic developmental state was limited in its ability to mobilize internal and external networks needed for technology innovations.

As globalization is thus threatening necessary or sufficient conditions of Northeast Asian developmental states, the question is how to alter the developmental state's role, and how to channel the state's involvement more effectively. The key issue is whether Northeast Asian states should become neo-liberalistic or developmentalistic in this era of globalization.

\section{Flexibility of Developmental States in Northeast Asia}

Northeast Asian states have attempted to promote the state's adaptability in the face of globalization. In other words, these states have been able to utilize the very process of globalization as a strategy for national economic development by adapting themselves to globalization rather than going against the globalization process. In this context, Northeast Asian states have actively sought to readjust production networks, given assistance to overseas development, and attracted foreign direct investment. ${ }^{23)}$ This adaptability has streamlined the search for new types of cooperation with private corporations that are expanding business activities on the global scale.

However, despite the changes in the financial system--a core part of developmental states--into a market-based one, there is no clear evidence that the developmental state has transformed into the regulatory state. First, the political, economic and social conditions in which the regulatory state can exist and sustain have not been created. And what is most important, market rationality is not sufficiently in place for Northeast Asian state to remain as the regulatory state. There is still a need for the developmental state to play a role in the growth of strategic industries and state intervention in the financial reform process. But these circumstances do not imply the perpetuity

22) Seung-Gook Ahn, "An Integral Analysis on the East Asian Economic Crisis: Focusing on the links between internal and external factors," The Korean Journal of International Relations, 42-3(2002), pp.61-62.

23) Linda Weiss, The Myth of the Powerless State (Ithaca: Cornell University Press, 1998), pp.202-4. 
of the bureaucratic developmental state. Since the internal and external conditions that helped to sustain the bureaucratic developmental state are undergoing change, it can be said that Northeast Asian states are in a transition period.

Unlike the developmental state, the regulatory state is based on free market principles. The regulatory state, contrary to the developmental state, is guided by regulations for fair market competition, rather than by blanket intervention in economic affairs. Consequently, the regulatory state does not cause market distortions by promoting strategic industries, rather, it is the product of institutional regulations that facilitate the functions of an already mature market. ${ }^{24)}$

As can be seen in $\langle$ Table 1$\rangle$, the regulatory state, unlike the developmental state, relies on the stock market or the bond market for capital funding and uses a short-term economic strategy that focuses on shareholder gains and investor profit. In contrast to the developmental state, the regulatory state targets regulation itself and is oriented toward the domestic market. Moreover, the regulatory state typifies high consumption, low taxation, and low welfare costs, whereas the developmental state is characterized by high savings and investments.

[Table 1] Comparison of the Regulatory State and the Developmental State

\begin{tabular}{c|c|c}
\hline & Regulatory State & Developmental State \\
\hline Basis of Rationality & Market-Rational & Plan-Rational \\
\hline Main Goal & Regulation & Development \\
\hline Pilot Agency & No & Yes \\
\hline Industrial Policy & No & Yes \\
\hline Source of Capital Supply & Stock/Bond Market & Financial Market \\
\hline Economic Orientation & Short-tem, tactical & Long-term, strategic \\
\hline Impetus of Growth & High Consumption & High Savings \\
\hline Market Orientation & Domestic Market & International Market \\
\hline
\end{tabular}

Transitional developmental states differ from regulatory states representing neo-liberalism. In the wake of the economic crisis, Northeast Asian states have pursued neo-liberalistic reforms in order to address problems, yet these states are still characteristic of developmental states. The newly emerging state in Northeast Asia is willing and able to intervene in strategic industries, but at the same time, by refraining from excessive intervention it aims to enhance market principle. Given these facts, explaining the transformation of Northeast Asian state based on the regulatory state model would be both inappropriate and inaccurate.

If this is the case, how can we define the characteristics of Northeast Asian states that are changing to adapt to the globalizing economy? This paper highlights the flexibility of

24) Andrew Gamble, "Economic Governance," in Jon Pierre, (ed.), Debating Governance: Authority, Steering, and Democracy (Oxford: Oxford University Press, 2000), pp.128-32. 
developmental states. The flexible developmental state is similar to the regulatory state based on neo-liberalism in that it does not manipulate pricing and exchange rates and does not erect trade barriers, but only intervenes in the economy in order to create appropriate conditions for development. Unlike the bureaucratic developmental state, however, the flexible developmental state intervenes on a small scale and in a flexible manner. The flexible developmental state is based upon tight fiscal expenditures, the maintenance of appropriate wage levels and foreign investment. In terms of policy, the flexible developmental state combines a neo-liberalistic macroeconomic policy and a restrictive intervention policy.

Therefore, the flexible developmental state's neo-liberalistic policy includes stringent fiscal expenditures, tax cuts and wage freezes, whereas its developmental policy includes education and training, propelled by a state-driven plan to establish infrastructure. The flexible developmental state, as opposed to the bureaucratic developmental state that seeks micro-intervention in favor of large corporations, also provides more opportunity to small- and medium-sized businesses.

As can be seen in <Table 2>, the most commonly applied pattern in Northeast Asia is (2) and (3) Both have an overall strength in their ability to pursue development goals but their social features differ widely. And as the society becomes more powerful, the state's power is not weakened: It still has the ability to intervene.

\section{[Table 2] Pattern of State-Society Relations}

\begin{tabular}{l|l|l}
\hline & \multicolumn{1}{|c|}{ Strong State } & \multicolumn{1}{c}{ Weak State } \\
\hline \multirow{5}{*}{ Strong Society } & $\begin{array}{l}\text { (3) Flexible Developmental State } \\
\text { Japan(since 1970s) } \\
\text { South Korea/Taiwan(since mid-1980s) }\end{array}$ & Britain. USA \\
\hline Weak Society & $\begin{array}{l}\text { (2) Bureaucratic Developmental State } \\
\text { Japan(between post-war and 1970s) } \\
\text { South Korea/Taiwan } \\
\text { (between 1960s and mid-1980s) }\end{array}$ & (1)Predatory State \\
\hline
\end{tabular}

The flexible developmental state assumes the role of facilitator. It supports corporate establishment, attracts foreign direct investment, and offers local businesses the opportunity to participate in global production. Unlike the bureaucratic developmental state, it does not provide protection to local businesses from the market, and it does not encourage local businesses to enter a particular industrial sector. As such, a flexible developmental state is built on the premise of local businesses' motivation to participate. What the state does is provide businesses the opportunity. ${ }^{25}$ )

States secure flexible wages in its labor market by forming social partnerships, so that local businesses are competitive in new industrial sectors. An important question at this point: What are the conditions in which flexible developmental states can prolong their existence? Flexible developmental states are dependent on the consensus between labor unions and business associations and without this consensus their role is restricted. Also, flexible developmental states

25) For the Flexible Developmental State in Ireland, refer to Sean O'Riain, "The Flexible Developmental State: Globalizaion, Information Technology, and the Celtic Tiger," Politics and Society, 28-2(June, 2000). 
relying on foreign capital influx are susceptible to global economic cycles, which can cause uncertainties in capital intake.

Northeast Asian bureaucratic developmental states transformed themselves into flexible developmental states in the 1990s. And in the era of globalization, flexible developmental states have the capacity to create production network and technology innovation, attract foreign direct investment, and link local businesses with transnational corporations to promote development. This ability is based on multiple embeddedness.

In other words, states have the ability to effectively manage the economy through flexible government structure and the connection between local and transnational corporation. Flexible developmental states provide information on transnational corporations to local businesses for their connections, but the opportunity to utilize these connections is left to local businesses. States offer incentives to transnational corporations by implementing macroeconomic policies. Investment by transnational corporations follows neo-liberalistic policies, such as deregulation, however, the lack of regulation may cause vulnerability to international capital flows.

In the era of globalization, the role of flexible developmental states, as opposed to bureaucratic developmental states, is to guarantee ownership and to supply public needs, such as health care and education. States must guarantee macroeconomic stability, but at the same time, should not distort prices or disrupt trade and investment, which could undermine national economic development. Price distortions fuel inflation, which hinders growth, and such barriers to trade and investment ultimately curtail growth as well. Thus, the primary role of flexible developmental states should be limited to providing infrastructure for development and guaranteeing market freedom. Second, flexible developmental states should act as sponsors assisting the establishment of new firms. Such facilitation is accomplished through legal institutions, ownership, privatization of infrastructure, and liberalization of trade and investment.

In sum, the role of the flexible developmental state is confined to completing the infrastructure, and creating an environment conducive to investment by transnational corporations. ${ }^{26)}$ That is, the focus should be on nurturing human resources, improving labor technology and creating a flexible labor market. To this end, states must form a link between business associations and labor unions pursuant to cooperative tripartite agreements. States should also organize a consensus on the national level to secure labor flexibility. This type of state role can be seen as transcending the role of the regulatory state.

Moreover, the flexible developmental state model is acceptable to labor unions since it creates jobs, thus pushes unemployment down. It is also acceptable to businesses since it raises profitability. In the end, flexible developmental states pursue market-oriented economic policies and set the direction for overall development plan, and place the emphasis on industrial policy, which induces corporate economic activity. These abilities separate flexible developmental states from regulatory states.

26) Frederic C. Deyo and Richard F. Doner, "Introduction: Economic Governance and Flexible Production in East Asia," in Frederic C. Deyo, Richard F. Doner, and Eric Hershberg, (eds.), Economic Governance and the Challenge of Flexibility in East Asia (Boston: Rowman \& Littlefield, 2001), pp.18-21. 


\section{Conclusion}

The state's capacity is not only related to the formation of industrial policy, but also to the reduction of state intervention. The irony is that the more effective a state's economic intervention, the stronger its private sector power and interdependence. As a result of successful economic development in Northeast Asia, private businesses have enhanced their capacity and the states are undergoing transformation so that their roles meet the changing conditions.

In this context, Northeast Asian states are gradually expanding cooperative ties between government and business, and moving away from bureaucratic controls. Businesses are no longer considered subordinate to states, but they are receiving assistance from states as partners. States are encouraging direct loans from international financial institutions, attracting foreign direct investments, and readjusting production networks so that businesses can adapt to international market.

Strategic intervention of flexible developmental states may give Northeast Asian countries comparative advantages. Moreover, tranformation of developmental states enables parallel development of democratic regimes. In the early stage of industrialization, bureaucratic developmental states were influenced by authoritarian regimes, but with the deepening of industrialization, flexible developmental states were able to integrate democratic mechanisms into their systems.

Currently, Northeast Asian states are poised at the juncture of transforming into the development model by capitalizing on the reforms they undertook following globalization and economic crisis. There is a demand for the transformation from the old state model to the new one. It may be inevitable for Northeast Asian states to break away from the developmental state model and move toward the regulatory state model in the long run, but rapid contraction of the state's role may bring about negative effects.

In this sense, the transformation of Northeast Asian states should be neither the bureaucratic developmental state nor the regulatory state but should follow a third alternative that satisfies both the need to form actual market principles and allow for appropriate state intervention. In other words, deregulation is necessary to minimize side effects from state-driven industrialization and establish market principles, but reregulation is also needed to promote economic reform. Therefore, the transformation of the state model is dependent on blocking excessive state intervention, while finding the appropriate level of state intervention. In this context, the flexible developmental state that guarantees effective state intervention can be suggested as an alternative. 


\section{References}

Ahn Seung-Gook, "The Political Economy of Capital Accumulation: the structural change of the world economy and the East Asian NICs," The Korean Journal of International Relations, 36-3(1997).

Ahn Seung-Gook, "An Integral Analysis of the East Asian Economic Crisis: Focusing on the links between internal and external factors," The Korean Journal of International Relations, 42-3(2002).

Amsden Alice H, Asia's Next Giant: South Korea and Late Industrialization, (New York: Oxford University Press), 1989.

Balassa, Bela, The Newly Industrializing Countries in the World Economy, (New York: Pergamon), 1981.

Boyer Robert and Daniel Drache, (eds.), States against Market: the Limit of Globalization, (London: Routledge), 1996.

Deyo, Frederic C., "State and Labor: Modes of Political Exclusion in East Asian Development," in Frederic C. Deyo, (ed.), The Political Economy of the New Asian Industrialism, (Ithaca: Cornell University Press), 1987.

Deyo, Frederic C. and Richard F. Doner, "Introduction: Economic Governance and Flexible Production in East Asia," in Frederic C. Deyo, Richard F. Doner, and Eric Hershberg, (eds.), Economic Governance and the Challenge of Flexibility in East Asia, (Boston: Rowman \& Littlefield), 2001.

Evans, Peter, Embedded Autonomy: States and Industrial Transformation, (Princeton: Princeton University Press), 1995.

Gamble, Andrew, "Economic Governance," in Jon Pierre, (ed.), Debating Governance: Authority, Steering, and Democracy, (Oxford: Oxford University Press), 2000.

Haggard, Stephan, Pathways from the Periphery: The Politics of Growth in the Newly Industrializing Countries, (Ithaca, NY: Cornell University Press), 1990.

Hirst, Paul and Graham Thomson, Globalization in Question, (Cambridge: Polity), 1996.

Johnson, Chalmers, MITI and the Japanese Miracle: The Growth of Industrial Policy, 1925-1975, (Stanford: Stanford University Press), 1982.

Johnson, Chalmers, "Political Institutions and Economic Performance: The Government-Business Relationship in Japan, South Korea, and Taiwan," in Frederic C. Deyo, (ed.), The Political Economy of the New Asian Industrialism, (Ithaca: Cornell University Press), 1987.

Krasner, Stephen D., Defending the National Interest: Raw Materials Investments and U.S. Foreign Policy, (Princeton: Princeton University Press), 1978.

Migdal, Joel, Strong Societies and Weak States: State-Society Relations and State Capabilities in the Third World, (Princeton: Princeton University Press), 1988.

Ohmae, Kenichi, The End of the Nation State: The Rise of Regional Economies, (New York: The Free Press), 1995.

Önis, Ziya., "The Logic of the Developmental State," Comparative Politics, 24-1(October, 1991). O'Riain, Sean, "The Flexible Developmental State: Globalizaion, Information Technology, and the Celtic Tiger," Politics and Society, 28-2(June, 2000).

Strange, Susan, The Retreat of the State, (Cambridge: Cambridge University Press), 1996.

Wade, Robert, Governing the Market: Economic Theory and the Role of Government in East 
Asian Industrialization, (Princeton: Princeton University Press), 1990.

Weiss, Linda A., The Myth of the Powerless State, (Ithaca: Cornell University Press), 1998.

Weiss, Lind A. and John M. Hobson, States and Economic Development: A Comparative Historical Analysis, (Cambridge: Polity), 1995.

White, Gordon and Robert Wade, "Developmental States and Markets in East Asia: An Introduction," in Gordon White, (ed.), Developmental States in East Asia, (Sussex, Macmillan Press), 1988. 